\title{
Raising Interest Rates: IOER vs. OMO: Interest on Excess Reserves vs Open Market Operations
}

\author{
William H. Carlson ${ }^{1} \&$ Conway L. Lackman ${ }^{2}$ \\ ${ }^{1}$ Duquesne University (ret.), Pittsburgh, Pennsylvania, United States \\ ${ }^{2}$ International Consulting Group, Pittsburgh, Pennsylvania, United States \\ Correspondence: Conway L. Lackman, International Consulting Group, Pittsburgh, Pennsylvania, United States.
}

Received: April 8, 2017

doi:10.5430/ijfr.v9n1p142
Accepted: November 30, 2017

Online Published: January 1, 2018

\begin{abstract}
We demonstrate that IOER should make the excess reserves even larger, continuing the problem of monetary policy control and rewarding the banks for their policy errors fostering the Great Recession by giving them risk free returns on the \$2.5 trillion of idle funds that are benefiting no one except the banks themselves, or having the banks invest those idle funds in some useful manner such as helping finance the government deficit and fix our roads and bridges. The number 1 priority should be to get rid of the troublesome excess reserves and utilizing open market operations (OMO).
\end{abstract}

Keywords: monetary policy, banking policy

\section{Introduction}

This paper is about how short term interest rates should be raised, not when. The basic criticism of the current situation of near zero short term interest rates with one $.25 \%$ increase in Dec. 2015 is that they are not "normal". This brings up the question of what is "normal". A factor not mentioned, at least on CNBC, is the huge level of excess reserves held by the banks that are a result of the bank bailout from the Great Recession of 2008-9. Huge excess reserves are not normal either and there is a connection. To gain some perspective on what is normal and what is not the following table shows the 3mo TBill rate (i3mo) and Fed Funds rate (iff) along with excess reserves $(\mathrm{Re})$, deposits at banks (DpT), and excess reserves as a percent of deposits (re). Data came from the FRED data base of the St. Louis Fed and Banking and Monetary Statistics 1914-41, 1941-1970, and Federal Reserve Bulletins.

Table 1. Interest rates and excess reserve ratio

\begin{tabular}{lllllll}
\hline Year & i3mo & iff & re & Normal & Re & DpT \\
\hline 2015 & 0.03 & 0.12 & 23.71 & no & $2.524 \mathrm{t}$ & $10.643 \mathrm{t}$ \\
\hline 2014 & 0.03 & 0.09 & 25.32 & no & $2.565 \mathrm{t}$ & $10.131 \mathrm{t}$ \\
\hline 2010 & 0.14 & 0.17 & 14.53 & no & $1.028 \mathrm{t}$ & $7.077 \mathrm{t}$ \\
\hline 2006 & 4.73 & 4.96 & 0275 & yes & $0017 \mathrm{t}$ & $6.102 \mathrm{t}$ \\
\hline 2006 & 4.73 & 4.96 & 0275 & yes & $1.676 \mathrm{~b}$ & $6102 \mathrm{~b}$ \\
\hline 1995 & 5.94 & 5.84 & 0318 & yes & $1.012 \mathrm{~b}$ & $3184 \mathrm{~b}$ \\
\hline $1985 \mathrm{r}$ & 7.48 & 8.10 & 0388 & yes & $875 \mathrm{~b}$ & $2253 \mathrm{~b}$ \\
\hline 1985 & 7.48 & 8.10 & 0362 & yes & $816 \mathrm{~b}$ & $2253 \mathrm{~b}$ \\
\hline 1982 & 10.61 & 12.26 & 0211 & yes & $360 \mathrm{~b}$ & $1706 \mathrm{~b}$ \\
\hline 1979 & 10.07 & 11.19 & 0169 & yes & $224 \mathrm{~b}$ & $1324 \mathrm{~b}$ \\
\hline 1972 & 4.07 & 4.43 & 0286 & yes & $201 \mathrm{~b}$ & $703 \mathrm{~b}$ \\
\hline 1969 & 6.67 & 8.20 & 0446 & yes & $238 \mathrm{~b}$ & $534 \mathrm{~b}$ \\
\hline
\end{tabular}




\begin{tabular}{|c|c|c|c|c|c|c|}
\hline 1968 & 5.34 & 5.65 & 0686 & yes & $345 b$ & $503 b$ \\
\hline 1966 & 4.86 & 5.11 & 0823 & yes & $357 b$ & $434 b$ \\
\hline 1964 & 3.55 & 3.50 & 1053 & yes & $396 b$ & $376 b$ \\
\hline $1959 r$ & 3.38 & 3.23 & 1702 & yes & $446 b$ & $262 b$ \\
\hline $1959 \mathrm{v}$ & 3.38 & 3.23 & 1788 & yes & $446 b$ & $250 \mathrm{~b}$ \\
\hline 1957 & 3.23 & 3.11 & 2298 & yes & $517 b$ & $225 b$ \\
\hline 1954 & 0.95 & 1.01 & 3775 & yes & $775 b$ & $205 b$ \\
\hline 1950 & 1.20 & ---- & 4618 & yes & $83 b$ & $170 \mathrm{~b}$ \\
\hline 1949 & 1.12 & --- & 5123 & yes & $822 b$ & $161 b$ \\
\hline 1948 & 1.05 & ---- & 5283 & yes & $839 b$ & $159 b$ \\
\hline $1947 \mathrm{~h}$ & 0.82 & ---- & 5463 & yes & $884 b$ & $162 b$ \\
\hline $1947 \mathrm{~h}$ & 0.38 & ---- & 5354 & peg & $821 b$ & $153.3 b$ \\
\hline 1946 & 0.38 & ---- & 6005 & peg & $976 b$ & $157.5 b$ \\
\hline 1945 & 0.38 & ---- & 7081 & peg & $1.121 \mathrm{~b}$ & $158.3 b$ \\
\hline 1944 & 0.38 & ---- & 7747 & peg & $1.046 \mathrm{~b}$ & $135.0 \mathrm{~b}$ \\
\hline 1943 & 0.38 & ---- & 1.343 & peg & $1.510 \mathrm{~b}$ & $112.4 b$ \\
\hline 1942 & 0.34 & ---- & 2.924 & no & 2.668 & $91.25 b$ \\
\hline 1941 & 0.13 & ---- & 6.659 & no & $5.324 b$ & $79.95 b$ \\
\hline 1940 & 0.04 & --- & 8.623 & no & $6.326 \mathrm{~b}$ & $73.37 b$ \\
\hline 1935 & 0.17 & ---- & 4.167 & no & $2.469 \mathrm{~b}$ & $59.25 b$ \\
\hline 1930 & 2.49 & ---- & 0932 & yes & $55 \mathrm{~m}$ & $58960 \mathrm{~m}$ \\
\hline 1929 & 3.28 & ---- & 0730 & yes & $43 m$ & $58890 \mathrm{~m}$ \\
\hline 1923 & 3.93 & ---- & 0579 & yes & $26 \mathrm{~m}$ & $44920 \mathrm{~m}$ \\
\hline
\end{tabular}

$\mathrm{r}=$ revised, $\mathrm{h}=$ half, $\mathrm{t}=$ trillion, $\mathrm{b}=$ billion, $\mathrm{m}=$ million, $\mathrm{v}$ : prior to 1960 vault cash not included in required reserves.

\section{The Situation}

The table shows that normal excess reserves are below $1 \%$ and post 1959 below .10\%. The reason was that until 2008 excess reserves did not earn any interest and had an opportunity cost equal to the 3 mo TBill or Fed Funds rate (see the i3mo and iff rate graph from FRED and see that they move together almost perfectly). So banks had an incentive to keep excess reserves near zero. IOER will destroy this incentive because excess reserves will become a risk free earning asset for doing nothing. As the IOER rate rises excess reserves become more desirable not less. IOER makes the excess reserves problem worse. There are two periods of zero bound short term rates in the table: 1934-43 and 2008 to the present. It is not a coincidence that at the zero bound excess reserves are abnormally high. The oversupply of uninvited funds drives short term rates down. And when interest rates are near zero short term purchases of TBills such as at the Sep. 2015 rate of .03\% may not even cover administrative costs. As long as we have "excess" excess reserves we cannot be "normal". With IOER we will never return to normality. The reason is IOER will encourage banks to increase their excess reserves, not eliminate them.

Rightly or wrongly the Fed appears ready to start raising short term rates. See their interest rate projections in Appendix A. We believe there is a correct way to do it and an incorrect way.

\subsection{Two Ways to Raise Interest Rates}

The traditional method of managing interest rates has been to use open market operations (OMO) in which the Fed buys government bills, notes, and bonds to lower rates and sells them to raise rates. Explanation: Bond, note, and bill prices are inversely related to interest rates. Simple numerical example: Suppose a 1 year TBill sells for $\$ 980$. You get $\$ 1000$ back in a year and your interest is $\$ 20$. The interest rate is $20 / 980=2.04 \%$. Now suppose the Bill price 
drops to $\$ 970$. Then the return or interest rate will be $30 / 970=3.09 \%$. So, the way the Fed traditionally raised interest rates was to dump TBills on the market (sell TBills to the banks and public through approved bond dealers), depressing their price and raising their yield. OMO is a market based method of interest rate management. A feature of OMO is that while selling TBills to raise rates excess reserves will be reduced as banks purchase the bills, solving the "excess" excess reserves problem. Note: the Fed seems to prefer controlling the overnight bank lending rate known as the federal funds rate over a quarter point range rather than the TBill rate. The fed funds rate and TBill rate move together (Figure B upon request). Fine tuning of the fed funds rate can be done with purchase agreements (repos) and reverse repos.

\subsection{The Second Method}

In 2006 the Financial Services Regulatory Relief Act gave the Fed the power to pay interest to banks on their excess reserves (IOER is interest on excess reserves) beginning in 2011. This was accelerated to 2008 as part of the bank rescue effort. IOER places a floor under bank lending rates, an inverse version of the now repealed Regulation Q that placed an artificial ceiling on bank savings rates. The basic idea is that if the IOER rate is set at $1 \%$ banks will not lend or invest at rates (adjusted for risk) below 1\%. If IOER is raised to 3\% bank lending and investing rates including the fed funds rate will presumably go up by $2 \%$. IOER is not market based. It is just an edict by the Fed putting a floor under bank lending rates. Raise the floor, raise bank rates. How it spreads to other short rates such as TBills, commercial paper, and savings rates is discussed below. Interest on excess reserves is risk free to the banks for doing nothing. The reason the banks have the huge amount of excess reserves is because the Fed and Treasury had to bail them out after they caused the disaster of 2008-9 from the quantitative easing programs including the purchase by the Fed of $\$ 1.7$ trillion of mortgage backed securities, MBS. (Figure A upon request). We believe the banks should buy those MBS securities back, it is their own junk. Essentially, the banks are being rewarded for causing the 2008-9 crisis.

\section{Problems with IOER}

As the IOER rate goes up, "excess" excess reserves become more desirable because they earn more. We predict that as long as the Fed uses IOER we will have "excess" excess reserves which block the return to "normality". IOER reduces the opportunity cost incentive to invest excess reserves and will change the bank investing model. It is possible that a bank could be started which would invest only in excess reserves to get the IOER and make no loans. Such a bank could earn more than a TBill only money market fund. Currently the TBill rate is $.03 \%$, IOER rate is $.25 \%$ so an IOER bank is possible. Money market funds were invented to get around Regulation Q. When you regulate prices by non-market means there may be unintended consequences.

When IOER was conceived in 2006 excess reserves averaged \$1.67 billion. Today they are about \$2.552 TRILLION, more than a thousand times higher implying a huge future windfall for banks and a huge expense to the Fed. When a crucial factor in a procedure goes up even faster than Pentagon boondoggles one would think that some reconsideration is in order. But there has been little or no discussion of IOER at least not from the Fed.

In 1935 the Banking Act of 1935 gave the Fed a new tool, the ability to raise reserve requirements which it did in 1936 and 1937 with disastrous unintended consequences, namely the giant recession of 1937-8. IOER is a new and untested procedure. There could be another unintended consequence.

On September 17, 2015 the Fed released its forecast of short term rates averaging 3\% in 2018. See Appendix A. This would yield an IOER of $\$ 76.5$ billion (32\% of which is estimated to go to foreign banks). To put this in perspective bank pretax profits were $\$ 200$ billion in 2014 (google FDIC HSOB or see Appendix B). IOER income will be a huge boost to bank profits. We predict the bank lobby will be a fierce defender of IOER (just as it was of another beneficial financial price control back in the 1960s and 70s, Regulation Q).

\subsection{Can We Control Rates without IOER?}

We have in the past. The table shows that the TBill rate was pegged at .38\% from April 1942 to July 1947. See June Sep 1942 and Aug. 1947 Federal Reserve Bulletins on FRASER, and Hetzel and Leach Richmond Fed Quarterly Winter 2001 "The Treasury-Fed Accord" in Appendix C. It was very simple to control the rate. The Fed was ready to buy or sell 3moTbills at a price of $\$ 999.07$ giving interest of $\$ .93$ over 3 months. Rate calculation: $(1+$ $.93 / 999.07)^{\wedge} 4-1=.373 \%$. By the way, if the Fed wants the TBill rate to go to $.50 \%$ in December it would sell TBills at a price of $\$ 998.75$. Calculation: $(1+1.25 / 998.75)^{\wedge} 4-1=.501 \%$. Fine tuning can be done with repos to get the federal funds rate into its usual quarter point range. 


\section{The Fed Balance Sheet Problem}

Bailouts and quantitative easings have ruined the Fed's balance sheet for certain operations. In 2006 bank excess reserves were $\$ 1.7$ billion. The Fed held $28.43 \%$ of its portfolio or $\$ 221.5$ billion in short term securities ( 90 days or less). This was more than 100 times bank excess reserves. See the Annual Report of the Federal Reserve 2006. In mid November 2015 bank excess reserves were $\$ 2578.6$ billion, more than 300 times the Fed's $\$ 8.41$ billion in short term securities. Short term securities were only $.20 \%$ of the portfolio. Note: mortgage backed securities almost all over 10 years were 1744.1 billion, $41.3 \%$ of the portfolio up from zero in 2006. The rescue efforts ruined the Fed's balance sheet so that now it cannot raise interest rates by selling TBills because it has virtually none to sell. See Google "Fed balance sheet .4.1 Release" to get Item 2 "MaturityDistribution of Securities, Nov. 19, 2015" for the data.

\subsection{Fixing the Fed's Balance Sheet So That It Can Conduct Open Market Operations}

Back in December 2008 the Fed anticipated a balance sheet problem of the sort we have now. In an interview with reporter Jon Hilsenrath of the Wall Street Journal On Dec 10, 2008 two solutions were presented by the Fed. Google "Fed Weighs Debt Sales of Its Own - WSJ" or see Appendix D. In the first solution the Fed would issue its own version of Treasury Bills (called Fed Bills or FBills). The second is swapping Fed holdings of longer term Treasuries back to the Treasury (lowering Treasury interest expense) in exchange for an equal dollar value of TBills. Note: The Fed has swap agreements with foreign central banks, so why can't it have agreements with our own Treasury. Also, in WWII the Fed and Treasury worked together hand in hand. The Fed knew about the balance sheet problem and solutions seven years ago. The Fed can conduct open market operations if it has the will to do it.

\section{The Possibility of a Credit Crunch}

Price ceilings and floors can have unintended consequences. In 1969 there was an artificial ceiling on savings rates called Regulation Q. As interest rates rose on TBills and commercial paper (CP) above the Q limits on savings, sophisticated savers withdrew from their accounts and bought TBills and CP in the free markets. See Appendix E. This process was called disintermediation. With relatively less deposits the banks had less to lend so they jacked up loan rates. Loan volume dropped 5.3\% 1968-1970, but the loan-deposit profit margin went from $2.63 \%$ to $3.62 \%$ up 37.6\%. See Appendix F. The banks loved Reg Q because it essentially allowed the banks to collude to pay savers below free market rates. If banks had colluded on their own to limit interest on savings they would have been prosecuted under antitrust. Because of the bank lobby it took another 16 years to get rid of Q. The people who got crunched with higher rates and lower volume were personal loan customers, students, small business, and large business not credit worthy enough to go to the CP market. Big firms and sophisticated savers met in the CP market and were relatively unscathed. The banks profited as mentioned. What does this have to do with IOER? Reg Q was an artificial ceiling on a segment of the savings market. IOER is an artificial floor under a segment of the loan market, bank lending rates. It implicitly allows banks to collude to raise rates above free market levels on the same types of customers who got crunched in 1969-70 without being subject to antitrust. Again, large companies and savers can meet in the unregulated $\mathrm{CP}$ and bond markets. Bank loan volume will drop because of the higher rates but again the profit margin should soar. Bank profits should get two boosts; from the increased loan profit margin in addition to the IOER. Because loan volume drops banks will not need to compete vigorously for deposits so savings rates may rise but not to the extent of bank loan rates.

\subsection{Controlling Money and Credit}

Brunner and Meltzer modified Friedman's money stock formula which in simplified form is:

$$
\mathrm{M}=(1+\mathrm{k} / \mathrm{k}+\mathrm{rr}+\mathrm{re}) \mathrm{Ba}
$$

$\mathrm{Ba}$ is the monetary base (currency $\mathrm{Cp}$ plus total reserves $\mathrm{R})$ and $(1+\mathrm{k} / \mathrm{k}+\mathrm{rr}+\mathrm{re})$ is the money multiplier. $\mathrm{K}$ is the currency/deposit ratio which is constant in the short run, $\mathrm{rr}$ the required reserve ratio controlled by the Fed, and re the excess reserve ratio of Table 1. In normal times re is virtually zero meaning that with k constant the Fed has control of $\mathrm{M}$ through rr and Ba. But if re is substantially larger than zero the banks can challenge the control of the Fed either by lowering or raising re.

In 1935 then Chairman Marriner Eccles voiced a concern that the banks could recklessly lend out their excess reserves and start an inflationary boom. Similar statements come from the "hawks" today who want to raise rates to forestall inflation. If we had a normal re near zero we would not have this worry. This is another reason to reduce re through open market operations rather than increasing re through IOER. Adding to the confusion of the 1935 Bank Act testimony Eccles and Rep Alan Goldsborough combined to come up with the idea that "you can pull on a string (to restrain the economy) but you cannot push on a string (to stimulate the economy in a trap)". Or, the Fed may 
attempt to stimulate the economy by buying T-bills to put base money into the economy but if the increase winds up in excess reserves the stimulation effort will have no effect. That in fact has happened to the quantitative easings. See FRED for a plot of the huge increase in the monetary base Ba. But M2 growth has been modest because the increase in Ba has been offset by the rise of re in the denominator of the multiplier. See Appendix H.

\section{Conclusion}

The number 1 priority should be to get rid of the troublesome excess reserves. OMO can do it. IOER should make the excess reserves even larger, continuing the problem. It also is a choice of rewarding the banks for their bad behavior by giving them risk free returns on the $\$ 2.5$ trillion of idle funds that are doing no one any good except the banks themselves, or having the banks invest those idle funds in some useful manner such as helping finance the government deficit and fix our roads and bridges.

\section{Referemces}

Bowman, D., E .Gagnon, \& M. Leahy. (2010). Interest on excess Reserves: The Experience of Foreign Central Banks. Board of Governors of the Federal Reserve System, 1-47.

Bullard, J. (2010). Seven Faces of the Peril. Federal Reserve Bank of St. Louis Review, Sep/Oct., 92, 339-52.

Financial Services Regulatory Relief Act 2006.

FRED, St. Louis Fed and Banking and Monetary Statistics 1914-41, 1941-1970, and Federal Reserve Bulletins.

Friedman, M. (1959). A Program for Monetary Stability. Fordham University Press.

Goodfriend, M. (2002). Interest on Reserves and Monetary Policy. Federal Reserve Bank of Richmond, 1-8.

Hetzel, \& Leach. (2001Winter). The Treasury-Fed Accord. Richmond Fed Quarterly, 11-14.

Hilsenrath, Jon. (2008, Dec 10) Fed Weighs Debt Sales of Its Own. Wall Street Journal, 25-29.

Keister, T., \& J. McAndrews (2009). Why Are Banks Holding So Many Excess Reserves? Federal Reserve Bulletin of New York, 15.8, 1-10.

Thornton, D. (2015). Requiem for QE. CATO Institute, 783, 1-34. 